\title{
IDENTIFICATION OF OCCUPATIONAL DISEASES, HEALTH RISK, HAZARD AND INJURIES AMONG THE WORKERS ENGAGED IN THERMAL POWER PLANT
}

\author{
Abhaynath Kumar ${ }^{1}$, Shishir Mohan Shrivastava', N.K. Jain ${ }^{3}$, Praveen Patel $^{4}$ \\ ${ }^{I}$ M.tech Student, Department of Fire technology and Safety Engineering, IES-IPS Academy, Indore (M.P), India \\ ${ }^{2}$ M.E. Student, Department of Mechanical Engineering, NITTTR Bhopal, (M.P), India \\ ${ }^{3}$ Professor, Department of Fire technology and Safety Engineering, IES-IPS Academy, Indore (M.P), India \\ ${ }^{4}$ Professor, Department of Fire technology and Safety Engineering, IES-IPS Academy, Indore (M.P), India
}

\begin{abstract}
Thermal power plant uses coal as fuel for their working. Coal after burning leaves ash. Disposal of this ash is also one important task. Ash comes in contact with open environment and has adverse effects on health of human being. Due to these various health problems like skin diseases, breathing problem etc. are started in man working under those premises. Some other elements like boiler, turbine, generator, material handling are those elements due to which hazards and accidents take place while operation and maintenance of these. This work focuses on identification of various Occupational diseases and injuries, health risks associated with the man power working in thermal power plant. This data were collected by questionnaires and personnel interview of the workers working in different section of the thermal power plant like boiler section, turbine \& generator section, coal \& ash handling plant, hydrogen plant etc. Analysis is done in terms of different variables, such as age, skills experience, type of injuries and type of diseases. Results are shown in the form graph and chart. The results indicate a remarkable and visible impact on health of workers during operation and maintenance.
\end{abstract}

Key Words: Occupational hazards and Diseases, health risk, Injuries, Questionnaires, Personnel interview.

\section{INTRODUCTION}

Thermal power plant has caused environmental impacts at all stages of the process in the area. It also caused various occupational diseases and injuries to the workers working. Each Occupational disease and injury has a major effect on economy due to loss of productive hour, man-power losses, compensation to the victim's. Due it this reason for reduction of all occupational diseases, injuries/fatalities, corrective and preventive measures should be done.

There are several kinds of ailments which were recorded in the thermal power plant. These included Allergic reactions that interfered with breathing, asthma , emphysema ,chronic bronchitis, Lung cancer, pneumonia, tuberculosis, wheezing, stroke, Chest pain, shortness of breath, cough, irregular heartbeat, swelling in legs and feet (not caused by walking), skin allergies, High B.P, anxiety, eye irritation and fatigue.. There are several legal parameters which are proposed and regulated by the government and other safety organizations. These parameters are essential to be followed up for safe working operation and conditions.

Risk $=$ Consequence $\times$ Likelihood

Some common safety rules and regulations which are essential in the power plant to follow up given in the:

- Factories Act 1948 \& M.P./C.G. Rules 1962
- The Indian Boiler Act 1923 \& Regulations, 1950 (Amendment 2007)

- Water Act -1974

- Hazardous Waste (Management \& Handling) Rules, 1989.

- Indian Electrical Act 2003 \& Rules 1956

- IS Standards

- OSHA Standard 1970

- Third Schedule (See section 89 and 90), List of Notifiable Diseases ,The factories Act,1948

Breaches of these laws and regulations generate hazards which can cause the harm by generating;

- Unsafe act

- Unsafe conditions

- Behavioral mishaps

In present scenario of visited thermal power plant we have seen the various breaches of laws and hazardous conditions which may lead to the threats to the people, property and environment.

\section{TERMINOLOGY}

Accident- A sudden event that results in an undesired outcome such as property damage, bodily injury or death. 
Occupational accident- Accident occurring at the workplace which may cause damage to machinery, tools or people.

Injury- Physical damage to body tissues caused by an accident or by exposure to environmental stressors. This injury may lead to death and is then called a "fatal accident" or may cause partial disability or lead to sick leave for a period of time.

Hazard- Any existing or potential condition in the workplace which, by itself or by interacting with other variables can result in death, injury, property damage or other loss. Simply, hazard is a potential source of harm.

Risk- The likelihood of harm (in defined circumstances).

Harm- The loss to a person (or people) as a consequence of damage.

Damage - The loss of inherent quality suffered by an entity (physical or biological).

Danger - The degree of exposure to a hazard.

Safety - The absence of danger.

Occupational safety - Risk identification at the workplace and preventive measures takes to reduce or eliminate the hazard which may lead to accident.

Safe behaviour- Acting in such a way that no risk of injury is caused by one's behaviour.

Safety professional- A person whose basic job function and responsibility is to prevent accidents and other harmful exposures and the personal injury, disease or property damage that may ensure.

Occupational Health: The protection and promotion of the health of workers by preventing and controlling occupational diseases and accidents and by eliminating occupational factors and conditions hazardous to health and safety at work.

Health Hazards- When work is associated with health hazards, it may cause occupational diseases, be one of the multiple causes of other diseases or may aggravate existing ill-health of non-occupational origin. In developing countries, where work is becoming increasingly mechanized, a number of work processes have been developed that treat workers as tools in production, putting their health and lives at risk. The occupational health lessons learned during the industrial revolution should be borne in mind in planning for health developing countries if such problems are to be avoided.

Occupational Hygiene- This is the practice of assessment and control of environmental factors and stresses arising in or from the workplace, which may cause injury, sickness, impaired health and well-being or significant discomfort and inefficiency among workers or among the citizens of the community.

It encompasses the study of:

- Toxicology

- Industrial processes

- The chemical and physical behaviour of air contaminants.

- Environment sampling techniques and statistics

- The design and evaluation of ventilation systems

- Noise control

- Radiation protection

- The health effects of occupational hazards
Occupational Diseases- Occupational diseases are adverse health conditions in the human being, the occurrence or severity of which is related to exposure to factors on the job or in the work environment. Such factors can be:

- Physical: e.g. heat, noise, radiation, vibration, light.

- Chemical: e.g. solvents, pesticides, heavy metals, dust.

- Biological: e.g. microorganisms; virus, bacteria, protozoan, insect or other living organism.

- Ergonomic: e.g. improperly designed tools or work areas, repetitive motions.

- Psychosocial stressors: e.g. lack of control over work, inadequate personal support.

- Mechanical: These mainly cause work accidents and injuries rather than occupational diseases.

Techniques used in recognizing health hazards-

1. Material Inventory

2. Process Inventory

3. Walk-through occupational hygiene survey

4. Air-sampling programmes

\section{Exposure measurement techniques-}

These techniques are based on the nature of hazards and the routes of environmental contact with the worker, e.g.

- Air sampling can show the concentration of particulates, gases and vapours that workers may inhale.

- Skin wipes can be used to measure the degree of skin contact with toxic material that may penetrate the skin.

- Noise dosimeters record and electronically integrate workplace noise level to determine total daily exposure.

Aim of occupational safety-

The occupational safety philosophy has been developed in order to:

- Prevent need less destruction of health and waste of human and other resources.

- Raise the morale of workers

- Prevents inefficiency in the workplace due to the effects of accidents

- Prevents social harm caused by accidents

- Promote accident prevention.

Causes of occupational accidents and injuries

1. Human factors

2. Environmental factors

\section{METHODOLOGY}

Methodology adopted for this work is based on the information available from the workers of different section and different age groups working in thermal power plant by the systematic questionnaire and personal interview. The main objective of this study is to find out the various occupational diseases, hazards, accidents and prepare a systematic safety measures to minimize them. The interview can be conducted randomly on 100 workers.

Questioners and checklist against which this work can be conducted are as follows;

APPENDIX 1 - Occupational Questionnaire 


\section{EMPLOYEE FEEDBACK FORM}

Use this form to record any workplace health and safety hazards, and comments or suggestions for improvement regarding operation, maintenance, processes and procedures.

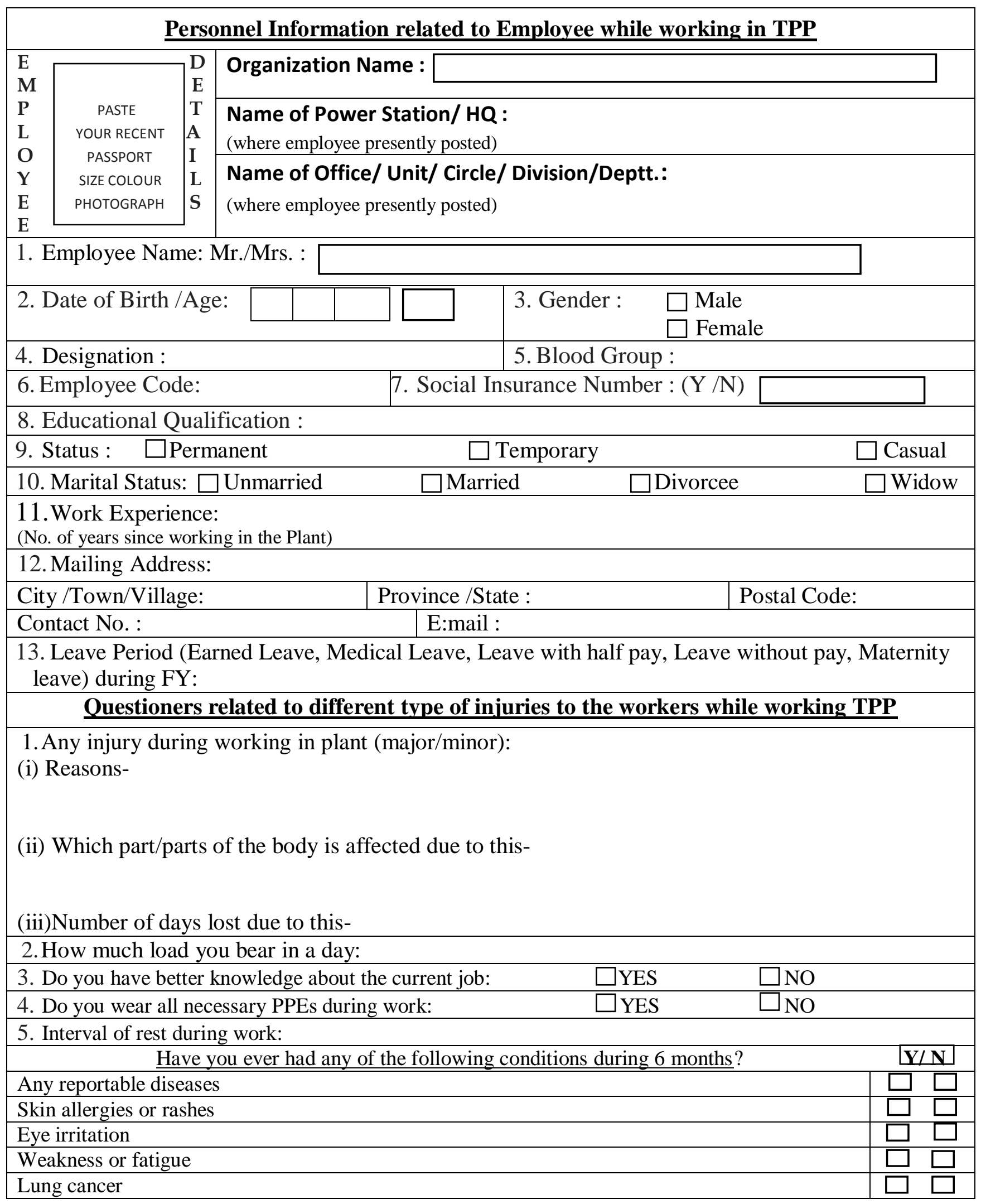




\begin{tabular}{|l|c|}
\hline Chest injuries or surgeries & $\square$ \\
\hline Asthma as an adult & $\square$ \\
\hline Pneumonia in the last month & $\square$ \\
\hline Tuberculosis & $\square$ \\
\hline Kidney diseases & $\square$ \\
\hline Respiratory allergy due to dust & $\square$ \\
\hline Hearing Problem & $\square$ \\
\hline \multicolumn{1}{|c|}{ Pulmonary or Lung illness during 6 months? } \\
\hline Shortness of breath during activity & $\square$ \\
\hline Cough & $\square$ \\
\hline Wheezing Cardiovascular or heart problems during 6 months? & $\square$ \\
\hline & $\square$ \\
\hline Heart Attack & $\square$ \\
\hline Stroke & $\square$ \\
\hline Irregular heart beat & $\square$ \\
\hline Swelling in your legs or feet (not caused by walking) & $\square$ \\
\hline High B.P & $\square$ \\
\hline
\end{tabular}

(i)

Any other kind of Symptoms apart from this?

(ii)

\begin{tabular}{lll} 
Do you follow Health and safety rules : & $\square$ YES & $\square$ NO \\
\hline Do you provide first aid kits : & $\square$ YES & $\square$ NO \\
\hline Whether you have fire exits and fire extinguishers : & $\square$ YES & $\square$ NO \\
\hline Whether you report unsafe work and conditions: & $\square$ YES & $\square$ NO \\
Did you use your personal protective equipment : & $\square$ YES & $\square$ NO \\
\hline Have you deal with violent customers: & $\square$ YES & $\square$ NO \\
\hline Whether you work alone the procedures : & $\square$ YES & $\square$ NO \\
Will there is regular Inspections in plant & $\square$ YES & $\square$ NO
\end{tabular}

How you handle Emergency procedures:

Do you think you have any sort of health problem while working here?

Do you think thermal power plant is causing any kind of pollution or problem in area?

17. Are there any pollution control devices installed?

\section{EVALUATOR'S COMMENTS}

Areas where improvement is needed:

Specific goals for upcoming year :

Other :

Prepared by

This information is collected under the authority of the Organization plant head. The content is regarding workplace, Health, Safety and Occupational Diseases. This is done mainly to prevent people, property and Environment in plant in future. I will never disclose this data to any one and it will only be used for worker's safety.

\section{Employee Feedback:}

(Please record your comments or suggestions)

Date

Employee Signature

Name 
Table -1: Number of worker Interview

\begin{tabular}{|c|c|c|}
\hline Sr.No. & Worker's Age & $\begin{array}{c}\text { No. of worker Interview } \\
\text { in TPP }\end{array}$ \\
\hline 1. & Below 18 & NA \\
\hline 2. & Between 18-28 & 22 \\
\hline 3. & Between 29-40 & 33 \\
\hline 4. & Between 41-60 & 45 \\
\hline \multicolumn{2}{|c|}{ Total } & 100 \\
\hline
\end{tabular}

Table -2: Number of Workers Affected Diseases (Age wise)

\begin{tabular}{|c|c|c|c|c|}
\hline \multirow{2}{*}{ Sr. } & Diseases & \multicolumn{3}{|c|}{ Age } \\
\cline { 3 - 5 } & $\mathbf{1 8 - 2 8}$ & $\mathbf{2 9 - 4 0}$ & $\mathbf{4 1 - 6 0}$ \\
\hline 1. & $\begin{array}{c}\text { Skin allergies or } \\
\text { rashes }\end{array}$ & 1 & 2 & 3 \\
\hline 2. & Eye irritation & & 1 & 1 \\
\hline 3. & $\begin{array}{c}\text { Weakness and } \\
\text { fatigue }\end{array}$ & 8 & 1 & 12 \\
\hline 4. & Asthma & 1 & 1 & 1 \\
\hline 5. & Tuberclosis & & 3 & 7 \\
\hline 6. & Allegy due to dust & & 1 & 2 \\
\hline 7. & Hearing problem & 1 & 3 & 9 \\
\hline 8. & Shortness of breath & 1 & \multicolumn{3}{|c|}{} \\
\hline
\end{tabular}

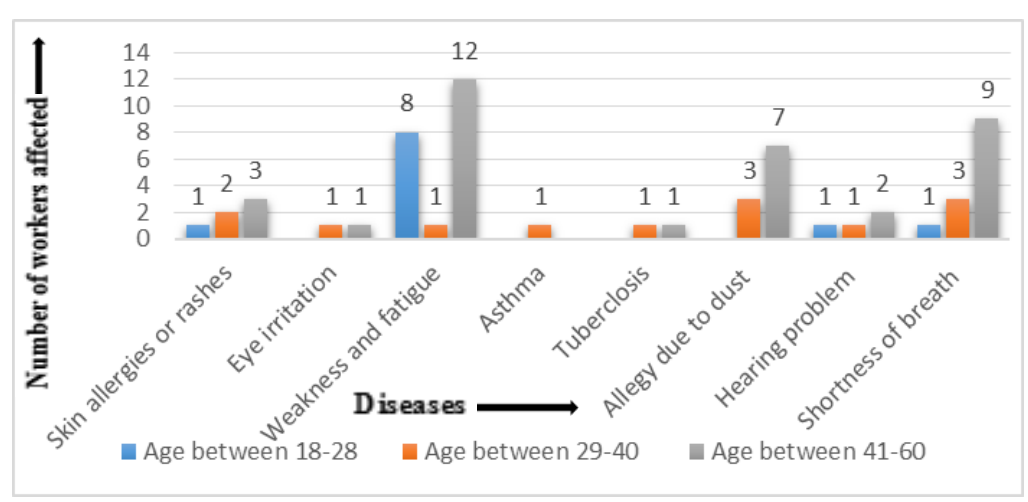

Chart-1: Shows the Number of workers affected by diseases in various section of Thermal Power Plant (Age wise)

Table -3: Year Wise Accident

\begin{tabular}{|c|c|c|c|c|}
\hline \multirow{2}{*}{$\begin{array}{l}\text { Sr. } \\
\text { No. }\end{array}$} & \multirow{2}{*}{$\begin{array}{c}\text { Year (1 } \\
\text { April To } \\
31 \text { March) }\end{array}$} & \multicolumn{3}{|c|}{ Types of Accident } \\
\hline & & $\begin{array}{l}\text { Near } \\
\text { Miss }\end{array}$ & $\begin{array}{l}\text { Reportable } \\
\text { (R) }\end{array}$ & $\begin{array}{c}\text { Non-Reportable } \\
\text { (NR) }\end{array}$ \\
\hline 1. & $2007-08$ & 2 & 1 & 2 \\
\hline 2. & $2008-09$ & 1 & 1 & 1 \\
\hline 3. & $2009-10$ & 2 & 1 & 2 \\
\hline 3. & $2010-11$ & 3 & 1 & 1 \\
\hline 4. & 2011-12 & 12 & 5 & 10 \\
\hline 5. & $2012-13$ & 3 & 3 & 3 \\
\hline 6. & $2013-14$ & 1 & 2 & 3 \\
\hline
\end{tabular}

\section{Number of Near Miss ,Repotable and Non-Repotable Accidents}

14

12

10

4

2

0

2007-08 2008-09 2009-10 2010-11 2011-12 2012-13 2013-14

Near Miss $\quad$ Reportable Non-Reportable

Chart-2: Shows the Near miss, Reportable and NonReportable accidents in Thermal power Plant

Table -4: Affected Body Parts/ Number of Injuries

\begin{tabular}{|c|c|c|}
\hline $\begin{array}{c}\text { Body } \\
\text { parts }\end{array}$ & $\begin{array}{c}\text { No. of } \\
\text { injury }\end{array}$ & $\begin{array}{c}\text { Percentage of Injury in } \\
\text { Body Parts (\%) }\end{array}$ \\
\hline $\begin{array}{c}\text { Hand } \\
\text { finger }\end{array}$ & 10 & 16.949 \\
\hline Arm & 5 & 8.474 \\
\hline Leg & 9 & 15.254 \\
\hline Nose & 1 & 1.695 \\
\hline Eye & 2 & 3.390 \\
\hline Head & 12 & 20.339 \\
\hline Shoulder & 8 & 13.560 \\
\hline Chest & 1 & 1.695 \\
\hline Back & 9 & 15.254 \\
\hline Skin & 2 & 3.390 \\
\hline Total & 59 & $100.00 \%$ \\
\hline
\end{tabular}

\section{Affected Body Parts Due to Injuries}

Skin

Back

Chest

Shoulder

Head

Eye

Nose

Leg

Arm

Hand finger

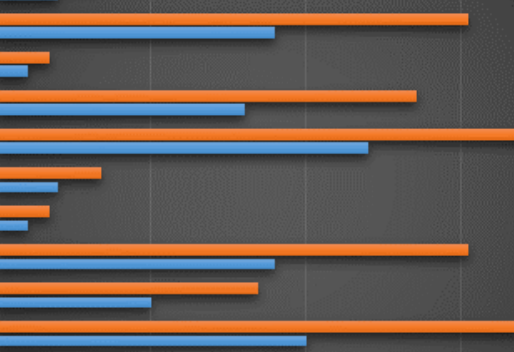

0

5

10

15

20

n Percentage of Injury in Body Parts (\%) №. of injury

Chart -3: Shows the Affected Body Parts Due to Injuries 


\section{Accidents in Thermal Power plant}

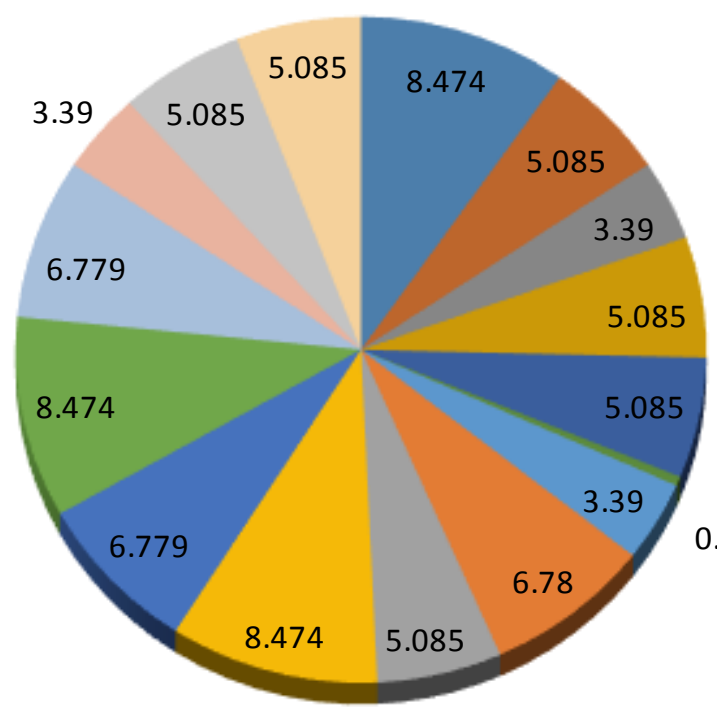

Chain Pulling
Plate cutting
Coal Yard
Coal Mill
Crusher House
Ash Hopper
Welding
Conveyor Belt
Bucket Elevator
Weight Lifting
Struck by object
Slip and trip on the operational area
Fall from the height
Accidents by transport vehicle
Burn
Electrical burn

Chart -4: Pie Chart representation of cause wise accidents in thermal power plant from 2007-2014

Table -5: Causes of Accident

\begin{tabular}{|c|c|c|}
\hline Accident Agent & $\begin{array}{l}\text { No. of } \\
\text { injury }\end{array}$ & $\begin{array}{l}\text { Percentage of injury by } \\
\text { Agent of Accidents }(\%)\end{array}$ \\
\hline Chain Pulling & 5 & 8.474 \\
\hline Plate cutting & 3 & 5.085 \\
\hline Coal Yard & 2 & 3.390 \\
\hline Coal Mill & 3 & 5.085 \\
\hline Crusher House & 3 & 5.085 \\
\hline Ash Hopper & 2 & 3.390 \\
\hline Welding & 2 & 3.390 \\
\hline Conveyor Belt & 4 & 6.780 \\
\hline Bucket Elevator & 3 & 5.085 \\
\hline Weight Lifting & 5 & 8.474 \\
\hline Struck by object & 4 & 6.779 \\
\hline $\begin{array}{c}\text { Slip and trip on the } \\
\text { operational area }\end{array}$ & 5 & 8.474 \\
\hline Fall from the height & 4 & 6.779 \\
\hline $\begin{array}{c}\text { Accidents by } \\
\text { transport vehicle }\end{array}$ & 2 & 3.390 \\
\hline Burn & 3 & 5.085 \\
\hline Electrical burn & 3 & 5.085 \\
\hline Electrical shock & 2 & 3.390 \\
\hline Stroked by object & 3 & 5.084 \\
\hline Others & 1 & 1.695 \\
\hline Total & 59 & $100.00 \%$ \\
\hline
\end{tabular}

Table -6: Causes of Plant Location Hazard

\begin{tabular}{|c|c|c|c|}
\hline $\begin{array}{l}\text { Sr. } \\
\text { No. }\end{array}$ & $\begin{array}{c}\text { PLANT } \\
\text { HAZARD } \\
\text { LOCATION }\end{array}$ & $\begin{array}{c}\text { HAZARD } \\
\text { DISCIPTION }\end{array}$ & PREVENTIVE MEASURE \\
\hline \multirow{9}{*}{1.} & \multirow{9}{*}{$\begin{array}{l}\text { COAL } \\
\text { HANDLING } \\
\text { PLANT }\end{array}$} & $\begin{array}{l}\text { Fire in coal } \\
\text { storage }\end{array}$ & $\begin{array}{l}\text { Regular inspection, water } \\
\text { spray, isolation from ignition } \\
\text { sources }\end{array}$ \\
\hline & & $\begin{array}{l}\text { Coal dust } \\
\text { explosion in } \\
\text { coal conveyer } \\
\text { bunker } \\
\end{array}$ & $\begin{array}{l}\text { Proper ventilation, spark proof } \\
\text { electrical equipment }\end{array}$ \\
\hline & & $\begin{array}{l}\text { Injury during } \\
\text { coal handling } \\
\text { like slip and } \\
\text { trip }\end{array}$ & Proper PPE's \\
\hline & & $\begin{array}{l}\text { Respiratory } \\
\text { problem due } \\
\text { to coal dust }\end{array}$ & Dust mask should be provided \\
\hline & & $\begin{array}{l}\text { Catches on } \\
\text { conveyer belt }\end{array}$ & $\begin{array}{l}\text { Safety guard on the moving } \\
\text { part }\end{array}$ \\
\hline & & $\begin{array}{l}\text { Rail line and } \\
\text { other transport } \\
\text { line accidents }\end{array}$ & Speed limit on plant area \\
\hline & & $\begin{array}{l}\text { Injury during } \\
\text { maintenance } \\
\text { on ball mill } \\
\end{array}$ & $\begin{array}{l}\text { Training, proper supervision, } \\
\text { PPE's }\end{array}$ \\
\hline & & $\begin{array}{l}\text { Fall from the } \\
\text { height during } \\
\text { work on } \\
\text { conveyer belt, } \\
\text { conveyer } \\
\text { control room } \\
\text { etc. }\end{array}$ & $\begin{array}{l}\text { Safety belt, safety net should } \\
\text { be provided, training }\end{array}$ \\
\hline & & $\begin{array}{l}\text { Struck by } \\
\text { falling object }\end{array}$ & Safety helmet, safety net \\
\hline
\end{tabular}




\begin{tabular}{|c|c|c|c|}
\hline \multirow{3}{*}{2.} & \multirow{3}{*}{ D.M. PLANT } & Fire hazard & $\begin{array}{l}\text { Fire extinguisher, eliminate the } \\
\text { possible ignition source }\end{array}$ \\
\hline & & $\begin{array}{l}\text { Chemical burn } \\
\text { by Spillage of } \\
\text { sulphuric acid } \\
\text { and caustic } \\
\text { soda lye } \\
\text { during } \\
\text { unloading, } \\
\text { overflow, } \\
\text { Damage on } \\
\text { storage tank or } \\
\text { pipe line }\end{array}$ & $\begin{array}{l}\text { Wash rinse exposed area, } \\
\text { training, maintenance, proper } \\
\text { supervision }\end{array}$ \\
\hline & & $\begin{array}{l}\text { High noise } \\
\text { level }\end{array}$ & $\begin{array}{l}\text { Ear plug, ear muff should } \\
\text { provided }\end{array}$ \\
\hline \multirow{10}{*}{3.} & \multirow{10}{*}{$\begin{array}{l}\text { BOILER } \\
\text { SYSTEM }\end{array}$} & $\begin{array}{l}\text { Explosion in } \\
\text { boiler due to } \\
\text { over pressure } \\
\text { and } \\
\text { temperature }\end{array}$ & $\begin{array}{l}\text { Continuous monitoring, } \\
\text { maintenance }\end{array}$ \\
\hline & & $\begin{array}{l}\text { Explosion in } \\
\text { boiler due to } \\
\text { improper } \\
\text { combustion of } \\
\text { fuel }\end{array}$ & $\begin{array}{l}\text { Regular inspection, } \\
\text { maintenance }\end{array}$ \\
\hline & & $\begin{array}{l}\text { Burn injury } \\
\text { due to hot } \\
\text { water and hot } \\
\text { steam pipeline } \\
\text { leakage }\end{array}$ & Inspection, maintenance \\
\hline & & $\begin{array}{l}\text { Exposure to } \\
\text { the hot surface } \\
\text { of pipeline or } \\
\text { machineries } \\
\end{array}$ & $\begin{array}{l}\text { Regular inspection, } \\
\text { maintenance }\end{array}$ \\
\hline & & $\begin{array}{l}\text { Water tube } \\
\text { burst due to } \\
\text { Failure in } \\
\text { boiler water } \\
\text { level control }\end{array}$ & $\begin{array}{l}\text { Continuous monitoring, } \\
\text { maintenance }\end{array}$ \\
\hline & & $\begin{array}{l}\text { Fire in diesel } \\
\text { supply line }\end{array}$ & $\begin{array}{l}\text { Regular inspection, } \\
\text { maintenance }\end{array}$ \\
\hline & & $\begin{array}{l}\text { Burn injury by } \\
\text { hot fly ash }\end{array}$ & Maintenance, proper exhaust \\
\hline & & $\begin{array}{l}\text { Catches on the } \\
\text { moving part of } \\
\text { the machinery } \\
\text { like F.D. fans } \\
\text { or motors }\end{array}$ & $\begin{array}{l}\text { Proper fencing on the moving } \\
\text { part of turbine }\end{array}$ \\
\hline & & $\begin{array}{l}\text { Burst of the } \\
\text { equipment } \\
\text { body due to } \\
\text { over pressure } \\
\text { and over } \\
\text { temperature }\end{array}$ & $\begin{array}{l}\text { Regular inspection, } \\
\text { maintenance }\end{array}$ \\
\hline & & $\begin{array}{l}\text { Sleep, trip } \\
\text { and from the } \\
\text { height during } \\
\text { routine work, } \\
\text { maintenance } \\
\text { or inspection }\end{array}$ & $\begin{array}{l}\text { Training, proper supervision, } \\
\text { PPE's }\end{array}$ \\
\hline \multirow{3}{*}{4.} & \multirow{3}{*}{$\begin{array}{c}\text { GENERATOR } \\
\text { AND } \\
\text { TURBINE }\end{array}$} & $\begin{array}{l}\text { Explosion in } \\
\text { turbine due to } \\
\text { cooling } \\
\text { system failure }\end{array}$ & $\begin{array}{l}\text { Regular inspection, } \\
\text { maintenance }\end{array}$ \\
\hline & & $\begin{array}{l}\text { Damage on } \\
\text { generator due } \\
\text { to lack of } \\
\text { lubrication in } \\
\text { coupling shaft }\end{array}$ & $\begin{array}{l}\text { Regular inspection, } \\
\text { maintenance }\end{array}$ \\
\hline & & $\begin{array}{l}\text { Fire on } \\
\text { cooling oil }\end{array}$ & $\begin{array}{l}\text { Proper storage, isolation from } \\
\text { the ignition sources }\end{array}$ \\
\hline
\end{tabular}

\begin{tabular}{|c|c|c|c|}
\hline & & $\begin{array}{l}\text { Fire and } \\
\text { explosion on } \\
\text { hydrogen tank }\end{array}$ & $\begin{array}{l}\text { Proper storage, isolation from } \\
\text { the ignition sources }\end{array}$ \\
\hline & & $\begin{array}{l}\text { High noise } \\
\text { level }\end{array}$ & $\begin{array}{l}\text { Ear plug, ear muff should } \\
\text { provided }\end{array}$ \\
\hline \multirow{3}{*}{5.} & \multirow{3}{*}{$\begin{array}{l}\text { SWITCH } \\
\text { YARD }\end{array}$} & $\begin{array}{l}\text { Fire on } \\
\text { transformer }\end{array}$ & $\begin{array}{l}\text { Regular inspection, } \\
\text { maintenance }\end{array}$ \\
\hline & & $\begin{array}{l}\text { Electric shock } \\
\text { and electric } \\
\text { burn routine } \\
\text { work, } \\
\text { maintenance } \\
\text { or inspection } \\
\text { of electrical } \\
\text { panels in } \\
\text { switch yard }\end{array}$ & $\begin{array}{l}\text { Training, PPE's should } \\
\text { provided }\end{array}$ \\
\hline & & $\begin{array}{l}\text { Slip, trip and } \\
\text { from the } \\
\text { height during } \\
\text { routine work, } \\
\text { maintenance } \\
\text { on switch yard }\end{array}$ & $\begin{array}{l}\text { Safety belt, safety harness } \\
\text { should provided, training }\end{array}$ \\
\hline \multirow{4}{*}{6.} & \multirow{4}{*}{$\begin{array}{c}\text { OTHER } \\
\text { HAZARD }\end{array}$} & $\begin{array}{l}\text { Control room } \\
\text { fire hazard }\end{array}$ & $\begin{array}{l}\text { Fire extinguisher, eliminate the } \\
\text { over heating }\end{array}$ \\
\hline & & $\begin{array}{l}\text { Eye irritation } \\
\text { and } \\
\text { respiratory } \\
\text { problem from } \\
\text { the exposure } \\
\text { of ammonia } \\
\text { leakage from } \\
\text { storage tank or } \\
\text { pipeline }\end{array}$ & $\begin{array}{l}\text { Wash rinse exposed area, } \\
\text { maintenance }\end{array}$ \\
\hline & & $\begin{array}{l}\text { Fire on } \\
\text { ammonia } \\
\text { storage tank }\end{array}$ & $\begin{array}{l}\text { Fire extinguisher, eliminate the } \\
\text { possible ignition source }\end{array}$ \\
\hline & & $\begin{array}{l}\text { Fire hazard on } \\
\text { fuel storage } \\
\text { tank }\end{array}$ & $\begin{array}{l}\text { Fire extinguisher, eliminate the } \\
\text { possible ignition source }\end{array}$ \\
\hline
\end{tabular}

\section{DATA ANALYSIS}

These data obtained by the questionnaire and personal interview was subjected to quantitative analysis. The percentage were calculate by simple mathematical formulas And results are shown in the form of graph and chart.

\section{CONCLUSIONS}

This work has been conducted by taking some variables like age, skills, and experience into consideration to get an overall view of occupational diseases, hazards and injuries among the workers of thermal power plant to enhance safety conditions of the plant. While conducting this study, it was found that workers of different age groups were mainly suffered from shortness of breath and fatigue. Most of the injured workers are highly skilled or unskilled. Overconfidence was found to be the main cause of injuries and near misses for skilled workers and lack of awareness, carelessness were common in unskilled workers. It is also found that different types of diseases generally happen in thermal power plant, some diseases also occurs like kidney 
diseases etc. In near future although these are not found in our diseases. This work also emphasizes on the main causes of accidents in thermal power plant, total number of accidents occur in past few years (from 2007 to 2014) and which body part got most affected due to these accidents. The main aim of this study is to find out the various occupational diseases, hazards and accidents in thermal power plant, also to find out a scenario of total occurrences of accident and their main causes.

\section{ACKNOWLEDGEMENT}

The authors thank to all the employee of thermal power plant, who participated in this study and shared their experience and information, as well as those who guided me to complete this work. I would specially like to thank Prof. N.K Jain, Fire Technology \& Safety Engg. Dept., IES, IPS Academy Indore \& Ex. Director of Industrial Health \& Safety, Government of M.P. for his valuable inspiration, able guidance and untiring help, which enabled me to carry out and complete this work. It's a great pleasure to thank Prof. Praveen Patel, Head of Department, Department of "Fire Technology \& Safety Engineering" IES, IPS Academy Indore, supported in my project. I express our sincere gratitude to Dr. Archana Keerti Chowdhary, Principal, Institute of Engineering \& Science, IPS Academy for extending all the facilities during the course of study. At this juncture I also take this opportunity to express our deep gratitude to all the Faculty members and Staff of Fire Technology \& Safety Engineering Department, for their appreciation and moral support. I am also thankful to all the persons who helped us directly or indirectly to bring the research paper work to the present shape.

\section{REFERENCES}

[1]. The Indian Factories Act 1948.

[2].Fundamentals of Industrial Safety \& HealthK.U.Mistry.

[3]. Syed Sana, Dr. G.A.Bhat and Henah Mehraj Balkhi, Health Risk Assocaited with workers of Cement factories ,International journal of scientific and research publications, volume 3, issue 5, may 2013. ISSN 2250-3153.

[4]. Salma A. Iqbal, Mohammed Iqbal, Md. Zubair Taufiq and Md. Shamim Ahmed, "Identification Of Occupational Injury Among The Workers Of Selected Cement Industries In Bangladesh", A Case Study, Journal of chemical engineering, Vol. chapter. No. 1, December 2010.

[5]. Material Safety Data Sheet of Silica.

[6]. Manjula R., R. Praveena, Rashmi R. Clevin, C. H. Ghattargi, A. S. Dorle, D. H. Lalitha, Effects of occupational dust exposure on the health status of Portland cement factoryworkers,ijmedph,feb12,2014.

[7]. Naman Agrawal and N.K. Jain "Identification of Occupational Diseases and Injuries among the Workers Engaged in Manual Material Handling of Cement Industry" International Journal on Emerging Technologies 5(1): 7881(2014), ISSN No. (Online): 2249-3255.

[8]. Ruchi Shrivastava and Praveen Patel, "Hazards Identification and Risk Assessment in Thermal Power Plant" International Journal of Engineering Research \&
Technology (IJERT), ISSN: 2278-0181, Vol. 3 Issue 4, April 2014.

[9]. Syed Sana Mehraj, G. A. Bhat, Henah Mehraj Balkhi, Taseen Gul "Health risks for population living in the neighborhood of a cement factory" African Journal of Environmental Science and Technology,( AJEST), Vol. 7(12), pp. 1044-1052, December 2013.

[10]. Rakesh Chib, Vikas Sharma "Health Risks Associated With Workers In Pesticide Factories" Indian Journal Of Applied Research, Volume: 4, Issue10, October 2014, ISSN - 2249-555X.

[11]. Occupational health a manual for primary health care workers-

http://www.who.int/occupational_health/regions/en/oehemh ealthcareworkers.pdf

\section{BIOGRAPHIES}

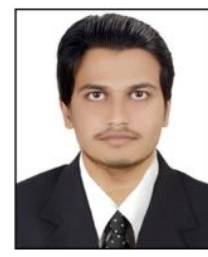

Abhaynath Kumar

(B.E. Mechanical Engg.) OIST, Bhopal (M.Tech. Industrial Safety Engg.) Deptt. of Fire Technology \& Safety Engg. IES, IPS Academy Indore (M.P.)

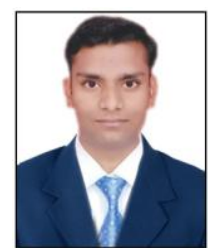

Shishir Mohan Shrivastava (B.E. Mechanical Engg.) OIST, Bhopal (M.E. Advance Production System) Department of Mechanical Engg. NITTTR Bhopal (M.P.)

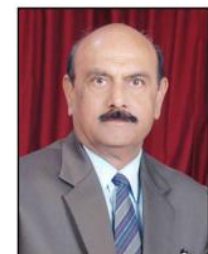

Prof. N. K. Jain

Ex. Director of Industrial Health \& Safety, Government of Madhya Pradesh Professor- Deptt. of Fire Technology \& Safety Engineering, IES, IPS Academy Indore (M.P.)

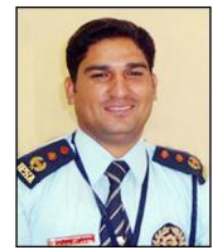

Prof. Praveen Patel

Head of Department, Department of Fire Technology \& Safety Engineering, IES, IPS Academy Indore (M.P.) 